Many researchers in the institutes say that the role of the academy's central office in the Palace of Science and Culture in Warsaw's city centre in governing the institutes has now diminished to the point that it is now time for the institutes to go their own way. The Academy's control over its institutes was formidable: until last year, Academy institute researchers wanting to travel abroad had to collect their passports from the Academy's offices. But those days are now gone, and institute directors now have little need to keep contact with Kuznicki, in managing their day-to-day affairs.

One idea that is much discussed is for the institutes to be reconstituted as inde-

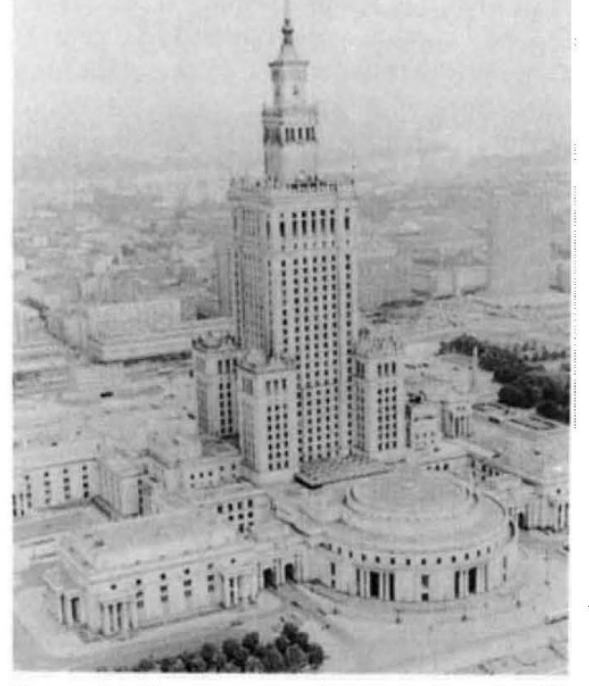

The Academy occupies part of the monumental Palace of Science and Culture.

pendent national laboratories, perhaps modelled on the institutes of the French Centre National de la Recherche Scientifique. But Wladyslaw Findeisen, one of the Academy's four vice-presidents, and as head of the Senat Commission on Science and Culture, one of the legislators who could help bring this change about, says that conflicting claims over the Academy of Sciences' name will prove a problem. Largely due to the relative strength of the Academy institutes in research, the Academy's title is seen as a badge of scientific quality. But as a member of the Academy proper, "I don't want people in independent institutes to take our name," says Findeisen. He is working hard to push through a new law to clarify the legal status of Polish research centres, which will make some private institutes eligible for state support - but this law has nothing to say about the Academy's institutes.

With little enthusiasm in parliament for rapid legislative reform, it seems that the main hopes for change must lie with the Academy itself. Critics say that this is a recipe for inaction, pointing out that Academy members have little incentive to press for reform. If the Academy does become simply the Polish equivalent of the Royal Society, there seems little justification for the substantial financial renumeration now given to its members. "They hate the Academy, but they love the money," is the harsh judgement from one of Poland's leading palaeobiologists, himself based in an Academy institute, speaking of the university professors whose salaries can be increased by 50 per cent or more by their membership of the Academy.

Kuznicki, who as scientific secretary is the real centre of power in the Academy (the post of president, held by the historian Aleksander Gieysztor, is largely a decoration), rejects the criticisms of the academy as a body resistant to change. Many of the Academy's critics are, he suggests, "frustrated professors" who have tried and failed to become members themselves. Since taking over as scientific secretary in January 1990, Kuznicki says that he has cut the Academy's adminis- trative staff by more than 70 to 190 people. Those remaining, and the stipends paid to the Academy members themselves, he believes are justified by the Academy's continuing functions. Apart the institutes, Kuznicki points out that the Academy is responsible for five laboratories abroad (including an Antarctic research station), six experimental farms, and numerous agreements for scientific cooperation with foriegn scientific organizations. Gieysztor is less bullish, accepting that "substantial changes" are needed.

Whatever the future shape of the Academy, it now has some healthy competition as Poland's premier academic body. Already, several of the historic learned societies dissolved to make way for the Academy in the early 1950 s, such as the Warsaw Society for Sciences and Arts and the Polish Academy of Knowledge in Krakow, have been restarted, and are flourishing.

\title{
Shoestring budget slows reform
}

\section{Gdansk \& Warsaw}

FOR Poland's universities as for the rest of society, the prospects for a better future are inextricably tied to the performance of the country's struggling economy. Asked to identify his priorities, Zbigniew Grzonka, rector of the University of Gdansk, puts invigorating the university's inefficient administration near the top of the list. Since taking over as rector in December 1990, Grzonka has found most of his time taken up with day-to-day administrative chores, rather than his plans for the university's future. The basic problem is money, and as Poland's economy falters, the universities cannot expect a rapid solution. The wages of university administrative and secretarial staff are pitifully low, and training in the past has been non-existent. When Maciej Zylicz joined Grzonka's team as prorector for scientific affairs, he says that many of his office staff would not even answer the telephone.

The salary problem also affects academics. A university professor earns around $\$ 200$ a month. Rents are low, but the prices of food and fuel are rising, and many professors must take second jobs. Not surprisingly, few students are opting for a life in teaching and research. "My brightest students tell me: 'Sorry, but I have to support my family'," says Tatiana Klonowicz, a University of Warsaw psychologist who supplements her income by interpreting at international conferences. This 'internal brain drain' is one of the main concerns of the education ministry, and of the state Committee for Scientific Research. But until the economy improves, scope for government action is limited. participation in higher education in Europe. In the absence of money to support a large increase to the country's 300,000 student population, the loss of academic staff and even the closure of some of Poland's institutes of higher education seems a distinct possibility, if the country's low ratio of teachers to students (around $1: 6)$ is to be brought in line with the European norm, of greater than 1:10. Although Poland has more than 100 such institutes, many of these are small, specialized schools, bearing little resemblence to a Western university.

One development that could invigorate the Polish university system would be the increased mobility of academic staff, who now tend to spend their careers tied to a single institution. The problem is the lack of a free market in housing: rented accommodation becomes available only after years, and mortgages are an unknown phenomenon. Polish researchers now find it easier to work abroad than to move between laboratories in their own country.

Some progress should be less constrained by the ecomony. University rectors hope to modernize the Polish system of undergraduate teaching, which is based around five-year masters degrees. Shorter courses leading to a western-style bachelors qualification would be more appropriate in today's Poland, and could attract more students, the rectors believe. For the universities to reform their courses, laws that require a masters degree for entry into many professions must be changed. But given the heavy demands on the Polish parliament's time, the widespread introduction of bachelors degrees Poland also has one of the lowest rates of may have to wait for several years. 